\title{
97. ROCZNICA ODZYSKANIA NIEPODLEGŁOŚCI PRZEZ POLSKĘ
}

W dniach 10-13 XI 2015 r. w Toruniu odbywały się w kilku miejscach miasta uroczystości z okazji 97. rocznicy odzyskania przez Polskę niepodległości. Muzeum Okręgowe na dziedzińcu Ratusza Staromiejskiego zorganizowało wystawę poświęconą legendarnemu lotnikowi Stanisławowi Skalskiemu z okazji setnej rocznicy urodzin. W dniu 10 XI 2015 r. delegacje złożyły kwiaty na Cmentarzu Komunalnym nr 1 pod obeliskiem ku czci poległych w latach 1918-1921.

Z kolei na Cmentarzu Komunalnym przy ul. Grudziądzkiej dokonano odsłonięcia nagrobku Jakuba Suleckiego, jednego z założycieli Towarzystwa Gimnastycznego „Sokół”, ofiary niemieckiego obozu koncentracyjnego. Tego dnia w Auli Uniwersytetu Mikołaja Kopernika odbył się koncert pt. "Kujawsko-Pomorskie Śpiewanie z Gwiazdami” (wystąpili Krzysztof Respondek, muzycy Filharmonii Pomorskiej, zespół Georgia Voices z Gruzji).

Punktem kulminacyjnym obchodów był dzień 11 listopada. Wówczas o godz. 11.40 delegacje $\mathrm{z}$ udziałem WP i władz miasta Torunia złożyły kwiaty pod pomnikiem gen. Józefa Hallera. Następnie w Kościele Garnizonowym pw. św. Katarzyny odbyła się uroczysta msza św. w intencji Ojczyzny, po której nastąpił przemarsz ulicami Starego Miasta pod pomnik marszałka Józefa Piłsudskiego. W marszu brały udział grupy rekonstrukcyjne przedstawiające husarię. Odbył się także przejazd „Marszałka Piłsudskiego" samochodem z epoki. Uroczystość patriotyczną rozpoczęło przyjęcie meldunku przez dowódcę Garnizonu Torun, podniesienie flagi państwowej i odegranie hymnu narodowego. Dowódca Garnizonu powitał gości, po czym nastąpiły przemówienia, apel poległych, oddanie salwy honorowej, złożenie wiązanek, wypuszczenie w niebo białych i czerwonych balonów oraz koncert Orkiestry Garnizonu Torun. Po południu odbył się piknik historyczny na Rynku Staromiejskim (pokaz współczesnego sprzętu służb mundurowych oraz rozdanie biało-czerwonych znaczków i chorągiewek, pokaz musztry paradnej w wykonaniu Orkiestry Garnizonu Torun oraz poczęstunek wojskową grochówką).

Świętowanie 97. rocznicy odzyskania niepodległości w Toruniu zakończono dnia 13 listopada o godz. 19.00 w Dworze Artusa koncertem Szymona Nehringa, finalisty XVII Międzynarodowego Konkursu Pianistycznego im. Fryderyka Chopina z Toruńską Orkiestrą Symfoniczną.

Anna Rojewska 